Ks. Norbert WIDOK

(Opole, UO)

\title{
WSKAZÓWKI IGNACEGO ANTIOCHEŃSKIEGO DO FILADELFIAN W SPRAWIE JEDNOŚCI KOŚCIELNEJ W OBLICZU DZIAŁALNOŚCI JUDAIZANTÓW
}

Biskup Ignacy, prowadzony przez żołnierzy z Antiochii do Rzymu, aby tam ponieść śmierć męczeńską, podczas dłuższego postoju najpierw w Smyrnie, a potem $\mathrm{w}$ Troadzie, miał możliwość kontaktowania się z delegacjami okolicznych wspólnot kościelnych, przedyskutowania z nimi aktualnych problemów duszpasterskich, a następnie po przemyśleniu poszczególnych kwestii, napisania do nich listu. W takiej sytuacji znalazła się także wspólnota chrześcijan w Filadelfii, która list Ignacego otrzymała z Troady. Należy bowiem uświadomić sobie, że to miasto na początku II wieku było siedzibą silnej grupy przestrzegającej zasad praktyk żydowskich. Ze względu na tę okoliczność warto, w oparciu o tenże list Antiocheńczyka, odkryć jego kościelne myślenie oraz poznać sugestie, jakie skierował do Filadejczyków w celu utrwalania jedności kościelnej.

1. Środowisko religijne ówczesnej Filadelfii. Filadelfia została założona w II wieku prz.Ch. przez Attalosa Filadelfosa, króla Pergamonu. Dzisiaj z tego miasta pozostały tylko ruiny w pobliżu Allaszer ${ }^{1}$. Powodem takiego końca dziejów miasta, geograficznie korzystnie położonego, były trzęsienia ziemi, choć za czasów Ignacego cieszyło się ono jeszcze ciągle sławą świetności². Religijne znaczenie Filadelfii zostało podkreślone przez autora Apokalipsy, który wśród siedmiu miast napisał także list do Kościoła w Filadelfii (Ap 3,713), czyniąc go „filarem w świątyni Boga” i miejscem objawienia „Nowego Jeruzalem". Tych faktów oczekiwali później montaniści, których początki działalności są właśnie związane z trzema małymi miejscowościami, leżącymi obok Filadelfii ${ }^{3}$. Chrześcijańskie znaczenie Filadelfii zostało także podkreślone w Męczeństwie św. Polikarpa, gdzie autor tego pisma wzmiankuje o śmierci męczeńskiej Polikarpa wraz z jedenastoma braćmi z Filadelfii ${ }^{4}$.

\footnotetext{
${ }^{1}$ Por. Mała encyklopedia kultury antycznej, red. K. Kumaniecki-K. Michałowski-L. Winniczuk, Warszawa 1983, 258.

${ }^{2}$ Por. Ch. Trevett, A study of Ignatius of Antioch in Syria and Asia, New York 1992, 92.

${ }^{3}$ Por. szerzej: J. Słomka, Nowe proroctwo. Historia i doktryna montanizmu, Katowice 2007, 48.

${ }^{4}$ Por. Martyrium Polycarpi 19, 1, SCh 10, 232, thum. A. Świderkówna, BOK 10, Kraków 1998, 168.
} 
Religijną panoramę tego miasta uzupełnia ponadto działalność prorocza kobiet. Z Filadelfii bowiem pochodziła prorokini Ammia, która działała prawdopodobnie w tym samym czasie, gdy Ignacy pisał list do Filadelfian. Wspominają ją zarówno katolicy, jak i montaniści ${ }^{5}$. Znane są również córki Apostoła Filipa, o których kilka świadectw przytacza w swej Historii kościelnej Euzebiusz z Cezarei ${ }^{6}$, a które swą aktywnością wyróżniały się w Azji. Papiasz z Hierapolis zaś odnosił się do nich z respektem ${ }^{7}$. Również apokryficzne Acta przedstawiają sylwetki różnych kobiet zajmujących się prorokowaniem, pośród których była m.in. Tekla ${ }^{8}$. Te różne odmiany kobiecej działalności prorockiej pojawiły się prawie równocześnie na początu II wieku, co było bardzo charakterystyczne dla struktury religijnej Filadelfii. Nie może zatem dziwić, że atmosfera duchowa miasta, złożona z tak wielu nurtów prorockich, stała się niebawem odpowienią pożywką dla powstałego tam montanizmu. Obok bowiem pokrótce wymienionych aspektów religijnego tła Filadelfii obecni byli w mieście Żydzi i judaizanci, którzy stali się głównym powodem ostrzeżeń i uwag umieszczonych w liście napisanym przez Ignacego do chrześcijan tego miasta.

2. Obecność judaizantów w Filadelfii. Jest kwestią bardzo charakterystyczną, że Ignacy z Antiochii, pisząc list do Filadelfian, ani razu nie nawiązał do prorockiej aktywności kobiet w tym mieście. Nigdzie też jasno nie wypowiedział się, czy wiedział o istnieniu tych kobiecych ruchów, a także, czy je akceptuje, czy też całkowicie odrzuca. Być może był w pełni świadomy obecności tych kobiet w publicznym życiu religijnym, albo też celowo nie chciał mieszać się w te sprawy, by niepotrzebnie nie wzniecać zamętu w mieście ${ }^{9}$. Te różnego rodzaju religijne ugrupowania Ignacy określił bardzo ogólnie, nazywając je „szkodliwymi chwastami”"10. Nigdzie jednak w swoim liście nie wymienia wprost, kogo ma na uwadze, mimo że stosunkowo często skarży się na istniejące podziały w społeczności filadelfijskiej. Słowo „podział” ( $\mu \varepsilon p ı \sigma \mu o ́ \varsigma)$ staje się w tym liście wręcz słowem-kluczem. Spośród 9 przypadków zastosowania tego terminu przez Ignacego w jego listach aż 6 razy użył go w liście do

\footnotetext{
${ }^{5}$ Por. Trevett, A study of Ignatius, s. 93.

${ }^{6}$ Por. Eusebius Caesariensis, HE 31, 1-4, SCh 31, 141-142, thum. A. Lisiecki, POK 3, 130-131.

${ }^{7}$ Por. tamże III 39, 9-10, SCh 31, 155-156, POK 3, 142.

${ }^{8}$ Por. Acta Pauli et Theclae, thum. M. Starowieyski : Apokryfy Nowego Testamentu, red. M. Starowieyski, t. II/1, Kraków 2007, 421-441; zob. Trevett, A study of Ignatius, s. 93 (autorka powołuje się na: S.L. Davies, The revolt of the widows: the social world of the Apocryphal Acts, London 1980).

${ }^{9}$ Por. Trevett, A study of Ignatius, s. 94.

${ }^{10}$ Por. Ignatius Antiochenus, Epistula ad Philadelphios 3, 1, SCh 10, 122, tłum. A. Świderkówna, BOK 10, 132: „Strońcie od szkodliwych chwastów, których Jezus Chrystus nie uprawia, bo nie sadził ich Ojciec".
} 
Filadelfian ${ }^{11}$. Natomiast jednocznacznie w tym liście odniósł się do judaizantów. Jedna z jego wypowiedzi brzmi bardzo wymownie:

„Jeśli ktoś wyjaśnia wam [Pismo] według zasad judaizmu, nie słuchajcie go. Lepiej jest bowiem słuchać obrzezanego, który głosi chrześcijaństwo, niż nie obrzezanego, który po żydowsku żyje. Jeśli ani ten, ani tamten nie mówi wam o Jezusie Chrystusie, są dla mnie obaj, jak kamienie i płyty grobowe"'2.

Treść przytoczonego tekstu jest u poszczególnych badaczy listów Antiocheńczyka intepretowana w sposób odmienny, co do niektórych szczegółów. Istnieje opinia, że judaizujący oponenci, których Ignacy wspomina, nie byli obrzezani ${ }^{13}$. Natomiast P.J. Donahue jest zdania, że autor tego tekstu zakłada różnice, istniejące pomiędzy chrześcijanami. I tak ktoś będący obrzezany mógł głosić Dobrą Nowinę, czego przykładem był św. Paweł, zaś środowisko pogan związanych z synagogą stało się ważnym źródłem nawróceń na chrześcijaństwo. Jest bowiem możliwe, by tego typu neofici, wychowywani według zasad judaizmu, mieli coś wspólnego zarówno z Prawem, jak i chrześcijaństwem. Przynależeli oni do wspólnoty kościelnej z jednej strony, a z drugiej - pełnili niektóre funkcje w środowisku żydowskim. Nie należy jednak przypuszczać, by ta przywołana przez Ignacego grupa chrześcijan brała aktywny udział w rozkrzewianiu obrzędowości żydowskiej. Niemniej jednak ich obecność była wystarczającym powodem do skomentowania przez niego tej kwestii ${ }^{14}$. Obok przynależności do danej grupy, tj. do chrześcijan judaizujących lub chrześcijan z nawróconych pogan, o wiele istotniejszym dla biskupa z Antiochii była treść przepowiadanych zasad. Według niego nie należało bowiem w ogóle wsłuchiwać się $\mathrm{w}$ wyjaśnianie zasad judaizmu, a jedynie tylko akceptować treści dotyczące Jezusa Chrystusa. Jeśli zatem czy to obrzezani czy nieobrzezani nie głosili Chrystusa, byli przez Ignacego traktowani ,jak kamienie i płyty grobowe".

Ignacy musiał ponadto bardzo ostrożnie podchodzić do judaizantów ze względu na znaczenie wydarzeń Starego Testamentu i jego odniesienia do nowej rzeczywistości objawionej przez Jezusa Chrystusa. Ta ostrożność widoczna jest w niektórych jego wypowiedziach. Pisał tak do Filadelfian:

„Proroków również kochajmy, ponieważ i oni zapowiadali Ewangelię, pokładali ufność w Chrystusie i na Niego czekali”"15.

Autor tych słów dostrzega powiązanie dziejów Starego i Nowego Testamentu, polegające na dopełnieniu dziejów zbawienia poprzez ich antycypację, wyrażoną nadzieją proroków, którzy stają się tym samym łącznikiem obu

\footnotetext{
${ }^{11}$ Por. Trevett, A study of Ignatius, s. 94.

${ }^{12}$ Ignatius Antiochenus, Epistula ad Philadelphios 6, 1, SCh 10, 124, BOK 10, 133.

${ }^{13}$ Por. C. Richardson, The Christianity of Ignatius of Antioch, New York 1967, 53.

${ }^{14}$ Por. P.J. Donahue, Jewish Christianity in the Letters of Ignatius of Antioch, VigCh 32 (1978) 89.

${ }^{15}$ Ignatius Antiochenus, Epistula ad Philadelphios 5, 2, SCh 10, 124, BOK 10, 133.
} 
Testamentów. W podobnym duchu Antiocheńczyk zaprezentował inną prawdę Starego Testamentu, gdy stwierdził:

„Godni byli również kapłani, ale większy od nich jest Arcykapłan, któremu powierzono tajemnice Boże. On jest Bramą Ojca, przez którą wchodzą Abraham i Izaak, i Jakub, i Prorocy, i Apostołowie, i Kościół. Wszystko to [prowadzi] do jedności z Bogiem"16.

Ignacy zatem nie tylko docenia proroków, do których odnosił się poprzedni passus, ale także kapłanów, którzy są „godni”, jednak prawdziwym kapłanem jest Arcykapłan Jezus Chrystus, będący „Bramą Ojca”. Przez tę Bramę wchodzą zarówno Patriarchowie i Prorocy, poprzez których należy rozumieć wszystkich ludzi Starego Testamentu, jak i Apostołowie i Kościół, a więc wspólnota Nowego Testamentu. Puentą tego passusu jest stwierdzenie, że wszyscy ci wymienieni są prowadzeni ku ,jedności z Bogiem”. Takie wyjaśnienia, przesłane do społeczności w Filadelfii, miały osłabić radykalizm myślenia u judaizujących chrześcijan ${ }^{17}$.

Obok powyższych stwierdzeń, w miarę życzliwie traktujących wyznawców judaizmu oraz żydujących chrześcijan, Ignacy w innym miejscu swego listu okazał się bardziej radykalny. Filadelfianie odczytali takie jego słowa:

„Zaklinam was, abyście niczego nie czynili w duchu kłótni, lecz według nauki Chrystusowej. Słyszałem, jak niektórzy mówią: «Jeśli nie znajdę tego w archiwach, czy w Ewangelii, nie uwierzę» [...]. Dla mnie archiwami jest Jezus Chrystus, archiwami nienaruszalnymi - to Jego krzyż, Jego śmierć i zmartwychwstanie" 18 .

Zapowiedziany wyżej radykalizm widoczny jest na początku przytoczonego tekstu, gdzie Ignacy umieścił napomnienie, by adresaci czegokolwiek nie wykonywali w atmosferze kłótni. Ignacy nie wymienił szczegółowych kwestii, jakie go nurtowały, ale prawdopodobnie dotyczyły one różnych spraw związanych z działalnością wspólnoty kościelnej w Filadelfii. Wezwał członków tej wspólnoty, aby w bieżących przedsięwzięciach nie towarzyszył im duch kłótni. Zakres tych spraw mógł dotyczyć interpretacji faktów zbawczych, przedstawionych na kartach ksiąg Starego Testamentu lub Ewangelii. W tym kontekście Ignacy posłużył się dosyć charakterystycznym słowem, tj. ,,archiwa", które było stosowane w kulturze hebrajskiej i greckiej. Tam pojęcie to oznaczało m.in. akta urzędowe, kroniki Fenicjan, pochodzenie kapłańskich genealogii. Natomiast w zastosowaniu Antiocheńczyka termin ten odnosi się tylko do ksiąg Starego Testamentu ${ }^{19}$. Jakby jednak na przekór takiemu od-

${ }^{16}$ Tamże 9, 1, SCh 10, 128, BOK 10, 134.

${ }^{17}$ Inne sugestie interpretacyjne odnośnie tego fragmetnu podaje W.R. Schoedel, Ignatius of Antioch. A Commentary on the Letters of Ignatius of Antioch, Philadelphia 1985, 209-210.

${ }^{18}$ Ignatius Antiochenus, Epistula ad Philadelphios 8, 2, SCh 10, 126-128, BOK 10, 134.

${ }^{19}$ Por. Schoedel, Ignatius of Antioch, s. 208. 
niesieniu dodał następnie, że dla niego samego archiwami są fakty Nowego Testamentu, a więc Jezus Chrystus, Jego krzyż, śmierć i zmartwychwstanie. Ignacy wymienił zatem te treści zbawcze, które podważali dokeci. Judaizm bowiem panujący w Filadelfii miał, jak się okazuje, doketystyczne podłoże ${ }^{20}$. W wypowiedzi Antiocheńczyka można więc dostrzec zlekceważenie dziedzictwa żydowskiego i zastosowanie pojęcia „,archiwa” w odniesieniu do nowej rzeczywistości. Takie potraktowanie treści Starego Testamentu jest swoistym sposobem przeciwstawienia się judaizującym chrześcijanom.

3. Sposoby osiągnięcia jedności kościelnej. Wobec sytuacji obecności głębokich i licznych podziałów wśród chrześcijan w Filadelfii, co wyżej pokrótce przedstawiono, Antiocheńczyk był przekonany, że jedynym sposobem usunięcia tych podziałów będzie zachęta, a właściwie napomnienie Filadelfian, do szukania dróg pogodzenia się i dojścia do jedności kościelnej. Według Ignacego, ostoją tej jedności jest tamtejsza hierarchia, stąd już na początku swego listu, w części przeznaczonej na pozdrowienia, wezwał adresatów słowami:

„Jesteście radością moją wieczną i trwałą, zwłaszcza jeśli wszyscy pozostajecie w jedności z biskupem, jego kapłanami i diakonami, wyznaczonymi po myśli Jezusa Chrystusa"21.

Akcent w tej wypowiedzi pada wprawdzie na radość, jaką Ignacy posiada, jednak tylko wówczas, o ile adresaci trwają w jedności ze swoją hierarchią. Takie ustawienie tej ważnej kwestii na początku listu pokazuje adresatom, na czym polega ideał kościelnej wspólnoty, na której Ignacemu tak bardzo zależało. To samo wezwanie Antiocheńczyk powtórzył w dalszej części listu ${ }^{22}$, by jego czytelnicy nie stracili wiodącej idei, jaką autor chciał im przekazać. Następnie raz jeszcze podkreśla wiodącą rolę biskupa:

„Nie czyńcie nic bez biskupa, [...], kochajcie jedność, unikajcie podziałów”23.

Trwanie przy biskupie, według Antiocheńczyka, jest sposobem na zachowanie jedności, a tym samym wyeliminowane wszelkich podziałów. Należy zauważyć, że Ignacy w obydwóch wypowiedziach wymienił biskupa, posługując się liczbą pojedynczą, co miało oznaczać zjednoczenie się wszystkich chrześcijan w mieście wokół jednego biskupa, nawet wówczas, gdyby ich było więcej. Ten styl zarządzania przejął on bez wątpienia z Antiochii, gdzie preferował charyzmatyczny urząd jednego biskupa ${ }^{24}$.

${ }^{20}$ Por. W. Uebele, ,, Viele Verführer sind in die Welt ausgegangen”. Die Gegner in den Briefen des Ignatius von Antiochien und in den Johannesbriefen, Stuttgart 2001, 82.

${ }^{21}$ Ignatius Antiochenus, Epistula ad Philadelphios (salutatio), SCh 10, 120, BOK 10, 132.

${ }^{22}$ Tamże 7, 1, SCh 10, 126, BOK 10, 134: „Trwajcie przy biskupie, kapłanach i diakonach”.

${ }^{23}$ Tamże.

${ }^{24}$ Por. A. Brent, Ignatius of Antioch. A Martyr Bishop and the origin of Episcopacy, New York 2007, 39-40. 
Powyższa zachęta odnosi się do zarządzania wspólnotą, a więc ma charakter dyscyplinarny. Wydaje się, że uporządkowanie spraw odnoszących się do zarządzania jest podstawą unormowania zasad należących do ortodoksji. Tam są bowiem odstępstwa i herezje, gdzie nie ma podporządkowania. W liście do Filadelfian znajduje się tekst, w którym zachodzi zespolenie tego, co dotyczy zasad wiary, z tym, co odnosi się do zarządu. Brzmi on następująco:

„Starajcie się zatem uczestniczyć w jednej Eucharystii. Jedno bowiem jest Ciało Pana naszego Jezusa Chrystusa i jeden kielich, by nas zjednoczyć z Krwią Jego, jeden ołtarz, jak też jeden biskup razem z kapłanami i diakonami, współsługami moimi”25.

Punktem wyjścia pouczenia antiocheńskiego biskupa, kierowanego do Filadelfian, jest Eucharystia, która bezprzecznie była dla każdego chrześcijanina sprawą wielkiej wagi. Wokół niej Ignacy buduje jedność kościelną i prosi, by przejąć jego myślenie. Następnie na zasadzie wyjaśnienia dodaje, że Eucharystia to Ciało i Krew Jezusa Chrystusa. Takie połączenie, czyli Eucharystii i Osoby Jezusa Chrystusa, wskazuje wyraźnie na ortodoksyjną postawę $e^{26}$, która wyklucza z jedności kościelnej inaczej myślących, zwłaszcza doketów ${ }^{27}$. Te zbawcze fakty - co mocno podkreśla Antiocheńczyk - odbywają się na ołtarzu, który jest jeden. Nie może w danej wspólnocie być kilka ołtarzy, gdyby tak było, świadczyłoby to o wewnętrznym podziale ${ }^{28}$. Wreszcie liturgię eucharystyczną może sprawować jeden biskup, który otoczony jest prezbiterami i diakonami. Również w tym tekście, podobnie jak wyżej, Ignacy zwraca uwagę na biskupa, który jest jeden, proponując tradycję znaną mu z Antiochii.

W powyższym fragmencie omawianego listu jedność, na której tak bardzo zależało Ignacemu, została podkreślona przez powtarzanie liczebnika ,jeden” przy poszczególnych fundamentalnych faktorach religii chrześcijańskiej, ponieważ jest jedna Eucharystia, jedno Ciało Chrystusa, jeden kielich, jeden ołtarz i jeden biskup. Należy też zauważyć, że wszystkie wymienione kategorie

${ }^{25}$ Ignatius Antiochenus, Epistula ad Philadelphios 4, 1, SCh 10, 122, BOK 10, 133.

${ }^{26}$ Por. więcej na ten temat: S.M. Gibbard, The Eucharist in the Ignatian Epistles, StPatr 8 (1966) 214-218; L. Wehr, Arznei der Unsterblichkeit. Die Eucharistie bei Ignatius von Antiochien und im Johannesevangelium, Münster 1987, 37nn; U. Bleyenberg, ,Im einen Leib seiner Kirche”. Zum Verhältnis von Eucharistie und Kirche bei Ignatius von Antiochien, „Trierer theologische Zeitschrift" 104 (1995) 120nn.

${ }^{27}$ Szeroką panoramę ich działalności w pierwszych wiekach chrześcijańskich przedstawia J.G. Davies, The origins of docetism, StPatr 6 (1959) t. 4, 13-35.

${ }^{28} \mathrm{Na}$ temat roli ołtarza w teologiczmym myśleniu Ignacego Antiocheńskiego por. N. Widok, Ottarz w eklezjologii Ignacego Antiocheńskiego, w: Sympozja Kazimierskie, t. 6: Ofiara - kaptanottarz w świecie późnego antyku, red. B. Iwaszkiewicz-Wronikowska - D. Próchniak, Lublin 2008, 117-123. 
są ściśle ze sobą połączone i zależne od siebie. Nie można bowiem odrywać jednej z nich od pozostałych, co zdarzało się ugrupowaniom schizmatyckim.

$* * *$

Wobec skomplikowanej sytuacji religijnej, jaka panowała w Filadelfii, biskup antiocheński zrezygnował $\mathrm{z}$ ostrej polemiki $\mathrm{i}$ walki $\mathrm{z}$ istniejącymi ugrupowaniami w tym mieście, o których wyżej wspomniano. Wprawdzie występują w liście adresowanym do Filadelfian treści zawierające sprzeciw, zwłaszcza wobec judaizantów, to są one jednak utrzymane w łagodnym tonie. Ignacy wybrał zatem drogę pojednawczego sposobu dotarcia do odbiorców jego sugestii, zachęt czy też próśb. Położył nacisk na szukanie jedności i dał im kilka propozycji, jak ją budować. Według niego można ją osiągnąć poprzez posłuszeństwu jednemu biskupowi, który sprawuje jedną Eucharystię. Antiocheńczyk świadomy pogmatwanego stanu religijnego w mieście, o czym dowiedział się podczas postoju w Troadzie, do siebie odnosi uwagę, pisząc: „Ja więc zrobiłem, co było w mej mocy, jako człowiek stworzony do jedności. Gdzie jest podział i gniew, tam Bóg nie mieszka"29.

\section{PRAECEPTA IGNATII ANTIOCHENI AD PHILADELPHIOS ECCLESIAE UNITATIS RATIONE OB IUDAIZANTIUM ACTIONES}

\section{(Argumentum)}

Huius dissertatiunculae tenor perpendit ecclesiae unitatem, quam Ignatius Antiochenus in Epistula ad Philadelphios expromit. Inter varios enim coetus religiosos in urbe Philadelphia significanter exstiterunt christiani inclinati ad iudaicam religionem. Ignatius illis praecepta introducenda in vitam christianam definit, quorum una Eucharistia et unus episcopus maximi momenti sunt. Oboedientia erga episcopum unus modus fit ad adipiscendam ecclesiae unitatem.

${ }^{29}$ Ignatius Antiochenus, Epistula ad Philadelphios 8, 1, SCh 10, 127, BOK 10, 134. 
